\title{
The Use of Pollution Indexes to Discriminate between Natural and Anthropogenic Heavy Metals in Soils
}

\author{
Katarzyna Sutkowska ${ }^{1}$, Leslaw Teper ${ }^{1}$, Tomasz Czech $^{2}$, Tomasz Hulok ${ }^{1}$, Michal Olszak ${ }^{1}$, Jan Zogala ${ }^{1}$ \\ ${ }^{1}$ Department of Applied Geology, Faculty of Earth Sciences, University of Silesia \\ Bedzinska 60, 41-200 Sosnowiec, Poland \\ katarzyna.sutkowska@us.edu.pl; leslaw.teper@us.edu.pl \\ ${ }^{2}$ Department of Agricultural and Environmental Chemistry, University of Agriculture in Krakow \\ al. A. Mickiewicza 21, 31-120 Kraków, Poland \\ Tomasz.Czech@ur.krakow.pl
}

\begin{abstract}
The aim of current study is the use of pollution indices to assess the influence of (1) the bedrocks, as a natural source of heavy metal in soil developed above them, and (2) anthropogenic pollutions (ore mining and processing) of the soil. The research was conducted in two areas, varying in terms of geological setting and type of land use, in the Upper Silesia Industrial Region, Southern Poland. The total $\mathrm{Zn}, \mathrm{Pb}$ and $\mathrm{Cd}$ contents (ICP-OES) for 39 topsoil samples were measured. All metal contents exceeded, from 2.5- to 42.4-fold, geochemical background levels. The selected pollution indices such as CF, CD, PLI and $\mathrm{I}_{\text {geo }}$ were calculated to indicate deterioration of topsoil quality due to metal pollution. Depending on the index used, we determined very high to moderate topsoil contamination. The influence intensity of particular metals differs between studied areas. It follows the order $\mathrm{Pb}>\mathrm{Cd}>\mathrm{Zn}$ for shallow historical mining area and the sequence $\mathrm{Zn}>\mathrm{Cd}>\mathrm{Pb}$ for area of deep mining and processing. Based on $\mathrm{I}_{\mathrm{geo}}$ values, we consider that the heavy metal content in the topsoil developed over the shallowly occurring ore bodies in dolomites is mainly (60\%) connected with natural presence of metals, while in the area where ore bodies are more deeply buried, the $90 \%$ of metal load is related to anthropogenic sources. Finally, we come to a conclusion that the realistic assessment of soil quality, according to heavy metal content, is possible only with the combined use of various pollution indices.
\end{abstract}

Keywords: Pollution indexes, Heavy metals, Soil contamination, Geogenic and Anthropogenic origin.

\section{Introduction}

Our study focuses on the assessment of the influence of (1) the bedrocks, as a natural source of heavy metal (HM) in soil developed above them and (2) anthropogenic pollutions (ore mining and processing) of the soil in the Upper Silesia Industrial Region, Southern Poland. Using ICP-OES, we measured total heavy metals ( $\mathrm{Zn}, \mathrm{Pb}$ and $\mathrm{Cd}$ ) content for topsoil samples developed over ore-bearing dolomites occurred at a different depth in two areas. The deterioration of topsoil quality due to metal pollution was accomplished by the selected pollution indices as CF, CD, PLI and $\mathrm{I}_{\text {geo }}$. The implementation of the $\mathrm{I}_{\text {geo }}$ index was employed to distinguish between the natural accumulation level and pollution load.

\section{Material and methods}

The research was conducted in two areas, varying in terms of the geological setting and land use, in the NE part of the Upper Silesia Industrial Region, Southern Poland. Both of the areas are built of Middle Triassic carbonate formation composed of dolomites, limestones and marls. The epigenetic fluid flow was responsible for the partial alteration of carbonate rock profile resulting in dolomitization [1]. The $\mathrm{Zn}-\mathrm{Pb}$ mineralization followed the dolomitization episode and the orebearing dolomites with the $\mathrm{Zn}-\mathrm{Pb}$ ore deposits developed [2]. In the Dlugoszyn area (D), the ore-bearing dolomites occur near the earth's surface, while in the Wilkoszyn area (W) ore bodies lay at a depth of 20 to 90 m. Relatively shallow occurrence of ore mineralization favoured the development of $\mathrm{Zn}-\mathrm{Pb}$ ore mining - the outcrop in the $\mathrm{D}$ area, and underground in the $\mathrm{W}$ area. The ore mining in the $\mathrm{D}$ area lasted from $12^{\text {th }}$ to $19^{\text {th }}$, while in the $\mathrm{W}$ area the deep mine with processing plant were abandoned in the middle of $20^{\text {th }}$ century [3-5].

The study was conducted on 15 soil profiles, mostly of the skeletal Rendzic Leptosol, sampled in the two areas. Each soil profile was divided into separate horizons. The 39 soil samples from topsoil layers were examined. Moreover, two bedrock specimens (one for each studied area) were sampled to assess a natural baseline $\mathrm{C}_{\mathrm{B}}$ of heavy metal concentration. 
The contents of $\mathrm{Zn}, \mathrm{Pb}$ and $\mathrm{Cd}$ in the topsoil were determined twice using atomic emission spectrometer ICP-OES. The HM contamination in soil samples were evaluated by applying contamination factor, CF [6]; degree of contamination, $\mathrm{CD}$ [6]; pollution load index, PLI [7, 8]; and index of geo-accumulation, $I_{g e o}$ [9]. The selected pollution index values were explained as proposed by Håkanson [6], for CF and CD; Zhang et al. [8], for PLI; and Müller [9], for Igeo.

\section{Results and discussion}

The concentrations of zinc, lead and cadmium in the soil differ significantly between the elevated (D) and the buried (W) ore-bearing dolomite areas. The investigated D soil samples contain $67.71-3328.74 \mathrm{mg} \cdot \mathrm{kg}^{-1} \mathrm{~d} . \mathrm{m}$. of $\mathrm{Zn}, 17.51-$ $1876.73 \mathrm{mg} \cdot \mathrm{kg}^{-1} \mathrm{~d} . \mathrm{m}$. of $\mathrm{Pb}$ and $0.1-37.58 \mathrm{mg} \cdot \mathrm{kg}^{-1}$ d.m. of Cd, with weighted arithmetic means $1350.64 \mathrm{mg} \cdot \mathrm{kg}^{-1} \mathrm{~d} . \mathrm{m}$., $549.54 \mathrm{mg} \cdot \mathrm{kg}^{-1}$ d.m. and $13.01 \mathrm{mg} \cdot \mathrm{kg}^{-1}$ d.m., respectively. The load of the same elements in the $\mathrm{W}$ area ranges as follows: 479.86 - $3077.48 \mathrm{mg} \cdot \mathrm{kg}^{-1}$ d.m. for $\mathrm{Zn}, 117.73$ - $1034.96 \mathrm{mg} \cdot \mathrm{kg}^{-1} \mathrm{~d} . \mathrm{m}$. for $\mathrm{Pb}$ and $2.34-27.66 \mathrm{mg} \cdot \mathrm{kg}^{-1} \mathrm{~d} . \mathrm{m}$. for Cd, with weighted arithmetic means $3632.02 \mathrm{mg} \cdot \mathrm{kg}^{-1}$ d.m., $961.73 \mathrm{mg} \cdot \mathrm{kg}^{-1}$ d.m. and $24.47 \mathrm{mg} \cdot \mathrm{kg}^{-1}$ d.m., correspondingly. The accumulations of HM in the D samples exceed 2.5-, 9- and 3.8-fold, the contents of $\mathrm{Zn}, \mathrm{Pb}$ and Cd in bedrock, respectively. The levels of metal concentrations in the $\mathrm{W}$ topsoil are over 42.4- (for $\mathrm{Zn}$ ), 11.9- (for $\mathrm{Pb}$ ) and 20-fold (for $\mathrm{Cd}$ ) higher than the baseline value. Significantly high HM levels assessed are similar to accumulations in soils observed in other sites impacted by the $\mathrm{Zn}-\mathrm{Pb}$ mining and smelting activity in Poland [10-15] and all over the world [16].

The $C_{B}$ values of $\mathrm{HM}$ concentration applied to the pollution indices equal [in $\mathrm{mg}^{\cdot} \mathrm{kg}^{-1} \mathrm{~d} . \mathrm{m}$ ] $551.79 \mathrm{of} \mathrm{Zn}, 60.83 \mathrm{of} \mathrm{Pb}$ and 3.41 of $\mathrm{Cd}$ for the $\mathrm{D}$ area, while in the $\mathrm{W}$ area, the $\mathrm{C}_{\mathrm{B}}$ values for $\mathrm{Zn}, \mathrm{Pb}$ and $\mathrm{Cd}$ reach 85.74, 81.01 and 1.22, respectively. To assess the degree of anthropogenic influence on the soils, the selected pollution indices such as CF, CD, PLI and Igeo were calculated.

The CF of $\mathrm{Zn}, \mathrm{Pb}$ and $\mathrm{Cd}$ in the Dlugoszyn area are in the range of 1.0-6.0, 2.8-30.6 and 2.1-9.6, respectively. They show the considerable to very high ( $80 \%$ of results for $\mathrm{Pb}$ ) and moderate to considerable (100\% for $\mathrm{Zn}$ and $80 \%$ for $\mathrm{Cd}$ ) topsoil contamination levels. In the Wilkoszyn area, $\mathrm{CF}$ has consecutive values for $\mathrm{Zn}, \mathrm{Pb}$ and $\mathrm{Cd}$ : 6.9-35.8, 1.1-6.1 and 1.9-22.6. Such CF levels point to the considerable to very high contamination degree with $\mathrm{Zn}$ (100\% of results) and Cd (90\%), and moderate to considerable pollution with $\mathrm{Pb}(80 \%)$.

The aim of calculating the $\mathrm{CD}$ index is to measure the degree of overall contamination of particular sample in the studied site. Based on the CD, $80 \%$ of calculated values for the Dlugoszyn samples are recognised as moderately-, while $20 \%$ of them as very high contaminated. In the Wilkoszyn samples, the considerable contamination (60\% of results) prevails over very high $(30 \%)$ and moderate $(10 \%)$ pollution of the topsoil.

Also the pollution load index (PLI) indicates deterioration of soil quality due to metal pollution. In the current study, it is seen that the PLI obtained for the Dlugoszyn samples allows to classify the topsoil pollution as moderate (20\% of results), moderate to high (40\%), high (20\%) and extreme (20\%), with values ranging from 1.8 to 12.1 , and mean equal 4.3 . In the Wilkoszyn samples, the PLI values from 1.9 to 16.5 , with mean 7.2, allow to assign examined topsoil to extremely- $(70 \%$ of results), very high- (20\%) and moderately- $(10 \%)$ polluted by $\mathrm{Zn}, \mathrm{Pb}$ and $\mathrm{Cd}$.

The $\mathrm{I}_{\text {geo }}$ ranges from -0.6 to 2.0 for $\mathrm{Zn}, 0.9$ to 4.3 for $\mathrm{Pb}$ and 0.5 to 2.7 for $\mathrm{Cd}$ in the Dlugoszyn area. The values of $\mathrm{I}_{\text {geo }}$ for analysed metals decrease in the sequence $\mathrm{Pb}>\mathrm{Cd}>\mathrm{Zn}$. Different situation is observed in the Wilkoszyn area where the $\mathrm{I}_{\text {geo }}$ varies in wide margins of $1.2-4.6$ for $\mathrm{Zn} ;-0.5-2.0$ for $\mathrm{Pb}$, and $0.3-3.9$ for $\mathrm{Cd}$. The pollution of the $\mathrm{HM}$ follows the order $\mathrm{Zn}>\mathrm{Cd}>\mathrm{Pb}$. Using the geoaccummulation index we can get the information about the potential source of pollution. The $I_{\text {geo }}$ values obtained for the elevated ore-bearing dolomites Dlugoszyn area show that baseline levels of pollution are mainly presented for zinc and cadmium, as $80 \%$ for $\mathrm{Zn}$ and $80 \%$ for Cd belong to uncontaminated/moderately contaminated, according to Müller's classification [9]. The only exception is for high pollution with $\mathrm{Pb}$. The $\mathrm{I}_{\text {geo }}$ provides evidence for geogenic source of most of zinc and cadmium and points to anthropogenic source of $80 \%$ of lead. For that reason, it might be assumed that the deterioration in soil quality is caused by lead in this location. In the Wilkoszyn area with the buried orebearing dolomites, moderate to heavy pollution by lead and cadmium is observed, as $80 \%$ for $\mathrm{Pb}$ and $90 \%$ for Cd belong to moderately/moderately to highly contaminated [9]. Concurrently, heavy to extreme pollution by zinc is identified, as 70\% for $\mathrm{Zn}$ belongs to highly/highly to extremely contaminated [9]. These results demonstrate that the metals in the topsoil of the Wilkoszyn location are of anthropogenic nature.

Diatta et al. [11] observed similar to ours, significantly high HM levels in soils impacted by the Miasteczko Slaskie Zinc smelter activity, in other part of the Upper Silesia Industrial Region. Applying the CF, CD and $\mathrm{I}_{\text {geo }}$, they determined the extremely high contamination for $\mathrm{Zn}, \mathrm{Cd}$ and $\mathrm{Pb}$ in ascending order [11]. Our findings differ slightly from those found in the 
literature in terms of the influence intensity of particular metals described above. In our opinion, the difference between the orders of pollutant intensity acquired for individual sites resulted primarily from the local industrial land use.

The historical mining of $\mathrm{Pb}$ ores could start in the Dlugoszyn area in the early medieval period, because well recognizable galena (lead sulfide) dominated there in shallowly occurring ore bodies and somewhat low melting point of lead made galena easy to processing [4]. This type of mining activity resulted in the most severe pollution by lead in the Dlugoszyn topsoil, and the levels of $\mathrm{Zn}$ and $\mathrm{Cd}$ come from the close proximity to the metal-rich bedrocks.

The very high zinc and lead contamination observed in the Wilkoszyn area most probably results from the XX century underground $\mathrm{Zn}-\mathrm{Pb}$ ore mining and processing. Not only galena but also zinc sulfides and nonsulfides were mined and processed in the area at that time. So, it seems probable that recently finished industrial operation is a principal cause of the great load of zinc and lead accumulated in the Wilkoszyn topsoil.

\section{Conclusion}

The application of the different pollution indices $\left(\mathrm{CF}, \mathrm{CD}, \mathrm{PLI}, \mathrm{I}_{\mathrm{geo}}\right)$ enable us to detect significant topsoil pollution with $\mathrm{Zn}, \mathrm{Pb}$ and $\mathrm{Cd}$ and reveal difference in the grade of topsoil contamination between the studied areas. Depending on the index used, we determined very high to considerable topsoil contamination. The influence intensity of particular metals differs between studied areas. In the place of shallow historical mining (the Dlugoszyn area), it follows the order $\mathrm{Pb}>\mathrm{Cd}>\mathrm{Zn}$, while in the place of deep mining and processing (the Wilkoszyn area) it decreases in the sequence $\mathrm{Zn}>\mathrm{Cd}>\mathrm{Pb}$. With the geo-accumulation index, it is possible to discriminate between natural and anthropogenic heavy metals in the soils developed over the ore-bearing formation in the two areas. Based on $\mathrm{I}_{\text {geo }}$ values, we consider that the heavy metal content in the topsoil developed over the shallowly occurring ore bodies in dolomites (the Dlugoszyn area) is mainly (60\%) connected with natural presence of metals. In the Wilkoszyn area where ore bodies are more deeply buried, the $90 \%$ of metal load is related to anthropogenic sources. Finally, we come to a conclusion that the realistic assessment of soil quality, according to heavy metal content, is possible only with the combined use of various pollution indices.

\section{Acknowledgements}

This study was performed in the framework of the statutory activities of the University of Silesia in Katowice and was funded by the University of Silesia, Faculty of Earth Sciences (grant number 1M-0413-001-1-01).

\section{References}

[1] D. L. Leach, J. G. Viets and J. W. Powell, "Textures of ores from the Silesian-Cracow zinc-lead deposits, Poland: clues to the ore-forming environment," Pol. Geol. Inst. Papers, vol. 154, pp. 37-50, 1996.

[2] M., Szuwarzynski, "Ore bodies in the Silesian-Cracow Zn-Pb ore district, Poland," Pol. Geol. Inst. Papers, vol. 154, pp. 9-24, 1996.

[3] D. Molenda, Mining of lead and silver in the Silesia-Cracow region up to the middle of the 16th century. Wrocław: Ossolineum, 1963.

[4] S. Panek, The history of lead and zinc ore mining in Jaworzno-Trzebinia-Chrzanow. (in Polish; unpublished), 1995.

[5] J. Cabala and K. Sutkowska, "Past exploitation and processing of $\mathrm{Zn}-\mathrm{Pb}$ ore influence on the industrial soil minerals composition, Olkusz and Jaworzno district," Prace Nauk. Inst. Górnictwa Polit. Wroct. Studia i Materiaty, vol. 117, pp. 13-22, 2006.

[6] L. Håkanson, "An ecological risk index for aquatic pollution controls sediment logical approach," Water Res., vol. 14, no. 2, pp. 975-1001, 1980.

[7] D. L. Tomlinson, J. G. Wilson, C. R. Harris and D. W. Jeffney, "Problems in the assessment of heavy metal levels in estuaries and the formation of a pollution index," Helgol. Wiss. Meeresunters., vol. 33, pp. 566-572, 1980.

[8] C. Zhang, Q. Qiao, J. D. Piper and B. Huang, "Assessment of heavy metal pollution from a Fe-smelting plant in urban river sediments using environmental magnetic and geochemical methods," Environ Pollut., vol. 159, no. 10, pp. 305770, 2011.

[9] G. Müller, "Index of geo-accumulation in sediments of the Rhine River," Geo. J., vol. 2, no. 3, pp. 108-118, 1969.

[10] J. Cabala and L. Teper, "Metalliferous constituents of rhizosphere soils contaminated by $\mathrm{Zn}-\mathrm{Pb}$ mining in southern Poland," Water, Air, Soil Pollut., vol. 178, pp. 351-362, 2007. 
[11] J. B. Diatta, E. Chudzinska and S. Wirth, "Assessment of heavy metal contamination of soils impacted by a zinc smelter activity," J. Elementol., vol. 13, pp. 5-16, 2008.

[12] K. Sutkowska, L. Teper, A. Vaněk, T. Czech and A. Baran, "Effect of historical zinc processing on soil: A case study in Southern Poland," in Proceedings of the 3rd World Congress on New Technologies (NewTech'17),Ottawa, 2017 Paper No. ICEPR 110.

[13] A. Baran, J. Wieczorek, R. Mazurek, K. Urbański and A. Klimkowicz-Pawlas, "Potential ecological risk assessment and predicting zinc accumulation in soils," Environ Geochem Health, vol. 40, no. 1, pp. 435-450, 2018.

[14] J. Wieczorek, A. Baran, K. Urbański, R. Mazurek and A. Klimowicz-Pawlas, "Assessment of the pollution and ecological risk of lead and cadmium in soils,” Environ Geochem Health, vol. 40, no. 6, pp. 2325-2342, 2018.

[15] V. Chrastný, A. Vaněk, L. Teper, J. Cabala, J. Procházka, L. Pechar, P. Drahota, V. Penížek, M. Komárek and M. Novák, "Geochemical position of $\mathrm{Pb}, \mathrm{Zn}$ and $\mathrm{Cd}$ in soils near the Olkusz mine/smelter, South Poland: Effects of land use, type of contamination and distance from pollution source," Environ. Monit. and Assess., vol. 184, no. 4, pp. 2517 2536, 2012.

[16] S. C. Obiora, A. Chukwu and T. C. Davies, "Heavy metals and health risk assessment of arable soils and food crops around $\mathrm{Pb}-\mathrm{Zn}$ mining localities in Enyigba, southeastern Nigeria," J. Afr. Earth Sci., vol. 116, pp. 182-189, 2016.

[17] G. Dziubanek, A. Piekut, M. Rusin, R. Baranowska and I. Hajok, "Contamination of food crops grown on soils with elevated heavy metals content," Ecotoxicol. Environ. Safety, vol. 118, pp.183-189, 2015. 